\title{
Conservation of Biodiversity and Poverty in Costa Rica: Analysis by Planning Regions
}

\author{
Conservación de Biodiversidad y Pobreza en Costa Rica: Análisis \\ por Regiones de Planificación \\ Michael Steven Arroyo-Zeledón \\ Escuela de Planificación y Promoción Social, Facultad de Ciencias Sociales, \\ Universidad Nacional, Costa Rica \\ michael.arroyo.zeledon@una.cr \\ Guillermo Zúñiga-Arias \\ Escuela de Planificación y Promoción Social, Facultad de Ciencias Sociales, \\ Universidad Nacional, Costa Rica \\ guillermo.zuniga.arias@una.cr
}

Recibido: 29/08/2017 • Aceptado: 15/11/2018

\begin{abstract}
One of the main strategies to preserve biodiversity has been the creation of protected areas, and some authors argue that such action will also have economic benefits for the human communities involved. Nevertheless, in several countries a spatial coincidence between these areas and poverty has been registered. This work evaluated whether there was more poverty in Costa Rican districts that have larger areas in inland national park or biological reserves. As an estimator of poverty in the districts, the Costa Rican index of social development (ISD) was used. For the whole country, districts with protected (DPA) areas had a lower ISD than those without them (DNPA). This result was also observed in the Central and Huetar Caribe planning regions; the opposite happened in the Huetar
\end{abstract}


Norte region. The differences between planning regions offer opportunities for further research.

Keywords: Conservation; Biodiversity; Poverty; Sustainability; Protected Areas; Costa Rica; Planning Regions

\section{RESUMEN}

Una de las principales estrategias para la conservación de la biodiversidad ha sido la creación de áreas protegidas, y algunos autores sostienen que esta medida también traerá beneficios económicos a las comunidades humanas involucradas. Sin embargo, en varios países se ha registrado una coincidencia espacial entre estas áreas y la pobreza. En este trabajo se evaluó si en los distritos de Costa Rica en los que existen áreas más extensas de parques nacionales o reservas biológicas había más pobreza. Para estimar la pobreza en los distritos, se usó el Índice de Desarrollo Social (IDS). Para todo el país, los distritos en los que existen áreas protegidas tenían un IDS más bajo que aquellos en donde no existen. Este resultado también se observó en las regiones de planificación Central y Huetar Caribe; lo contrario ocurrió en la región Huetar Norte. Las diferencias encontradas entre las regiones de planificación ofrecen oportunidades para nuevas investigaciones.

Palabras clave: conservación; biodiversidad; pobreza; sostenibilidad; áreas protegidas; Costa Rica; regiones de planificación

\section{INTRODUCTION}

Throughout the world, conservation of biodiversity has become one of the major goals in the agenda of many countries (Waldron et al., 2013). This is so because biological diversity and processes related to its preservation provide services that are essential to the survival of human populations (De Groot et al., 2012). Ultimately, the effectiveness of the different strategies intended to preserve biodiversity depends on numerous factors, including clearly stated and functional policies as well as human well-being (Figueroa, Sánchez-Cordero, Illoldi-Rangel \& Linaje, 2011).

One of the main strategies to preserve biodiversity has been the creation of protected areas. After their establishment in several regions, a spatial 
relationship between such areas and poverty was noticed (Sanderson, 2005, Fisher \& Christopher, 2007). That relationship seems to contradict the argument that protection of biodiversity also has economic benefits for the human communities involved (Adams \& Hutton, 2007; Ferraro \& Hanauer, 2014), and has given rise to a lengthy debate.

Much of the discussion has been focused on determining whether protected areas have increased or alleviated poverty. In Costa Rica, Andam, Ferraro, Sims, Healy, and Holland (2010) concluded that the creation of protected areas reduced poverty by $10 \%$ between 1973 and 2000. Nevertheless, according to Ferraro and Hanauer (2011), activities that limit conservation effectiveness of protected areas (such as deforestation) could have improved social welfare of the Costa Rican population.

On the other hand, in several African countries national parks have displaced and impoverished thousands of people (Cernea \& Schmidt-Soltau, 2006). Upton et al. (2008) pointed out that this happens because national parks limit agricultural development and exploitation of natural resources.

It is clear that protected areas were not originally created to have an impact on the economic well-being of human populations in any region of the world, but were rather intended to preserve biodiversity (Phillips, 2004). However, it has been recently argued that conservation of biological diversity can help alleviate poverty (Turner et al., 2012; Watson, Dudley, Segan, \& Hockings, 2014).

Beyond the debate on whether or not the establishment of protected areas increases or alleviates poverty, the presence of populations of poor people near these areas can have important effects. This situation can reduce the effectiveness of efforts to preserve biodiversity, since poor people living around protected areas may be tempted to use natural resources unsustainably to satisfy their basic needs (Adams et al., 2004). Andam et al. (2010) found that for the period 1973-2000, Costa Rican communities near protected areas were poorer than national averages, but their work was focused on poverty alleviation after the creation of these areas.

It has been argued that larger protected areas may deprive communities of more resources than smaller ones, and that more poverty would therefore be expected around the former (De Sherbinin, 2008), although this response 
might vary according to location (Ferraro, Hanauer, \& Sims, 2011). Although Costa Rica is a small country, economic and cultural characteristics vary considerably within its territory and the same could possible be seen in the relationship between poverty and protection of biodiversity.

The present work analyzed whether there was more poverty in Costa Rican districts that have larger areas of national parks or biological reserves, and if this relationship varied at different locations within the country, which adopted the protected areas system very early. A positive relationship between poverty and extension of land dedicated to conservation of biodiversity would inform government authorities of the need to verify the effectiveness of protected areas to preserve the country's biological diversity.

\section{METHOD}

\section{Study Site}

Costa Rica is located in CentralAmerica, with a continental area of approximately $51,100 \mathrm{Km}^{2}$ (Bertsch, 2006) and coastlines on the Caribbean Sea and the Pacific Ocean (Figure 1). It is a tropical country with 23 Holdridge Life Zones (Powell, Barborak, \& Rodriguez, 2000) distributed across large plains and mountain ranges that run across the country, from northwest to southeast. Costa Rica contains $4.75 \%$ of the Earth's biodiversity (Donato, 2011).

As one of its strategies to preserve its biological diversity, Costa Rica implemented a system of protected areas more than half a century ago (SINAC, 2010). The system encompasses a total of nine categories of protection, with the categories of National Park and Biological Reserve being the most restrictive (SINAC, 2007). According to the Costa Rican Biodiversity Law and its regulations, areas in these categories can only be used to conserve natural beauty and biodiversity.

The country has a population of $4,761,807$ inhabitants, $17.34 \%$ of whom are considered poor and $7.24 \%$ extremely poor (INEC, 2014a). The Poverty Line is the method used to measure poverty in Costa Rica since 1987, which is based on the cost of basic living expenses (INEC, 2010). In 2014 , the poverty lines in urban and rural areas were approximately 199 and 153 dollars per month, respectively (INEC, 2014b). Unfortunately, 


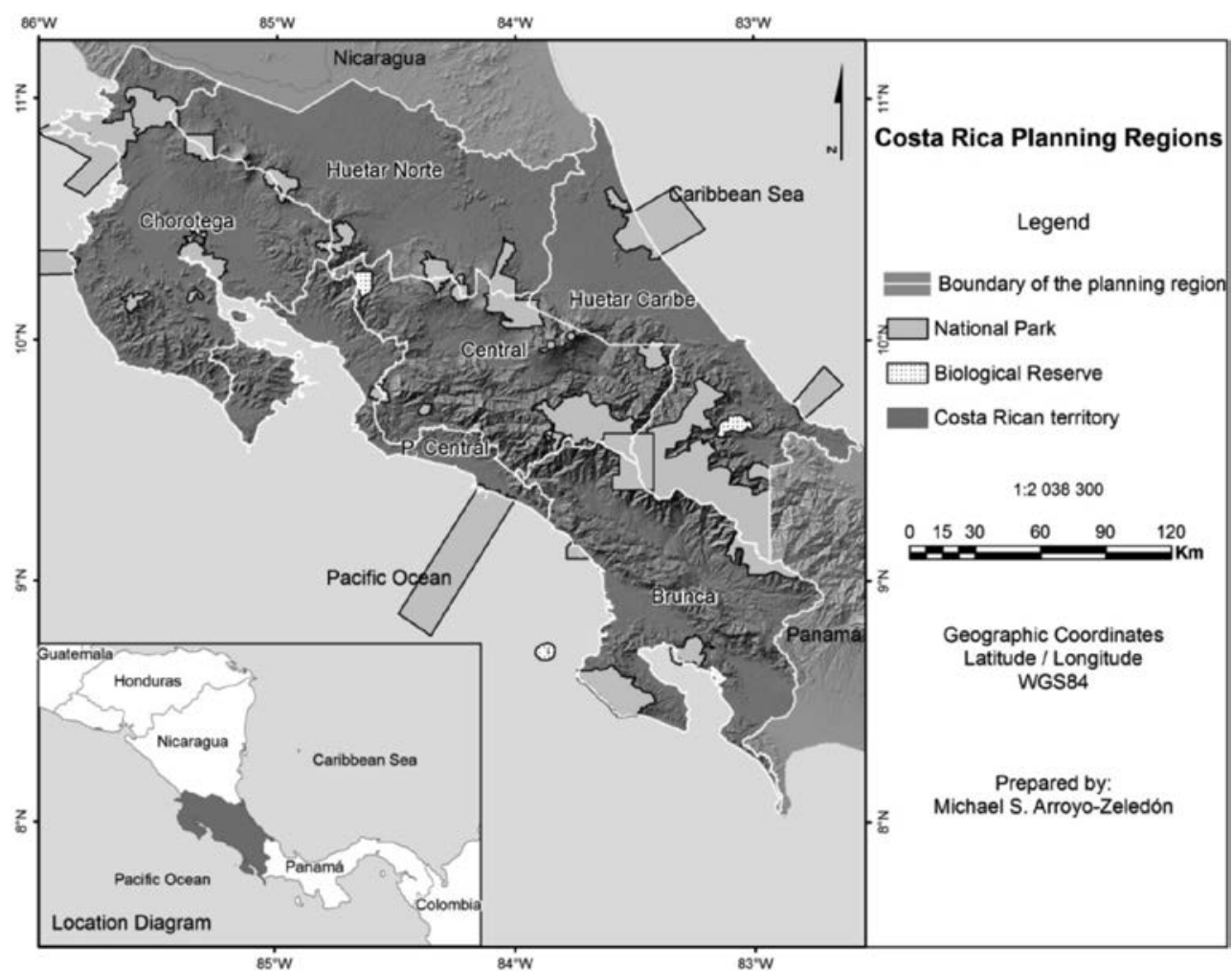

Figure 1. Costa Rican planning regions.

this method has not been applied in the smallest political-administrative divisions (districts). Only recently have governmental authorities started to work on a multidimensional poverty index.

There are three types of political-administrative divisions in Costa Rica, from the largest to the smallest: provinces, cantons and districts. In total, there are 7 provinces, 81 cantons and 483 districts. There is a municipality in each one of the cantons, which administers several districts. As mentioned above, Poverty Line data are not available at the district level.

To improve planning and coordination between governmental institutions, and hence the use of public resources (Alvarado, 2003), Costa Rica is divided into six regions: Central, Huetar Norte, Huetar Caribe, Brunca, Pacífico Central and Chorotega (Figure 1), which have traditionally been different in terms of their economic and social development (Alvarado, 2003). 


\section{Methodology}

In the absence of detailed poverty data at district level, the Costa Rican Index of Social Development (ISD) is used in this study as an indicator of poverty. The way in which the ISD is calculated makes it the closest approximation in the country to a multidimensional poverty index.

The ISD is a measurement of the social development of each Costa Rican district and is calculated by the Ministry of National Planning and Economic Policy (MIDEPLAN, 2013, 2017). At present, it has been measured for two years: 2013 and 2017. The 2013 measurement limited the number of districts considered in the analysis to 476 . The ISD includes a series of indicators grouped in four dimensions: economy, electoral participation, health and education (MIDEPLAN, 2013, 2017), and the higher the ISD of a district, the better its social development.

The size of the area occupied by national parks or biological reserves in the districts was calculated with the program ArcGIS 10.1, using the Protected Areas of Costa Rica and Districts of Costa Rica shape files available in the web map service provided by the National Geographical Institute of Costa Rica (IGN, 2014).

For the purposes of this analysis, only districts that contained significant extents of protected areas were included, and therefore only districts that had more than $5 \%$ of their territory under protection were considered. The national parks Marino Las Baulas, Manuel Antonio, Marino Ballena and Cahuita were not included since more than $90 \%$ of their areas are in the ocean. Therefore, 24 out of the 28 national parks in Costa Rica were included in this study. The four (out of eight) biological reserves located on the mainland (Lomas Barbudal, Alberto Manuel Brenes, Cerro Las Vueltas and Hitoy Cerere) were also considered.

Differences in poverty for districts with and without inland national parks or biological reserves were analyzed first. To do so, a Student's t-test was used, because previously a Kolmogorov - Smirnov test kept the null hypothesis of a normal distribution of data $(p=.2)$. These tests and all other tests carried out were performed using the program SPSS Statistics 21.0. This type of analysis was also carried out for each planning region of Costa Rica. 
A correlation analysis was then carried out to determine if poverty was higher in Costa Rican districts that had larger areas of national parks or biological reserves (with the exception of the Pacífico Central region, in which only one district, Tárcoles, had an area protected as a national park), using the ISD as a district-level poverty scale in which lower values indicate higher levels of poverty of people living in a given district.

The relationship between poverty and areas of national parks or biological reserves was also evaluated for every planning region of the country. This was carried out by planning regions of Costa Rica, since there have historically been differences in the socio-economic development of these regions. In 2013, average planning district ISDs ranged between 46 and 67 on a scale of 1-100 (MIDEPLAN, 2013).

\section{RESULTS}

As of $2013,17 \%$ of Costa Rican districts (80 out of 476 ) had more than $5 \%$ of their territory protected as national parks or biological reserves. When the entire country was considered, districts with protected areas (DPA) had lower ISD values than those without them (DNPA), and the difference was statistically significant. A similar result was found for the Central, Huetar Caribe, Pacífico Central and Chorotega regions, although the difference was not significant for the Chorotega region, and for the Pacífico Central region it was significant only in 2017 (Table 1).

Table 1

Index of social development (ISD) for districts with (DPA) and without (DNPA) protected areasa in the planning regions of Costa Rica. Mean \pm Standard deviation

\begin{tabular}{|c|c|c|c|c|c|c|}
\hline \multirow{2}{*}{ Planning Region } & \multicolumn{3}{|c|}{ IDS 2013} & \multicolumn{3}{|c|}{ IDS 2017} \\
\hline & DPA & DNPA & Significance $^{b}$ & DPA & DNPA & Significance \\
\hline \multirow{2}{*}{ Huetar Norte } & 51.3 & 43.1 & \multirow{2}{*}{ * } & 56.6 & 43.9 & \multirow{2}{*}{$* *$} \\
\hline & \pm 8.6 & \pm 11.9 & & \pm 8.2 & \pm 12.2 & \\
\hline \multirow{2}{*}{ Huetar Caribe } & 38.5 & 48.9 & \multirow{2}{*}{ ** } & 41.2 & 49.7 & \multirow{2}{*}{$* *$} \\
\hline & \pm 16.7 & \pm 5.0 & & \pm 13.8 & \pm 7.9 & \\
\hline \multirow{2}{*}{ Brunca } & 46.1 & 45.4 & & 46.7 & 48.5 & \\
\hline & \pm 8.9 & \pm 10.5 & & \pm 8.6 & \pm 10.9 & \\
\hline
\end{tabular}




\begin{tabular}{|c|c|c|c|c|c|c|}
\hline \multirow{2}{*}{ Planning Region } & \multicolumn{3}{|c|}{ IDS 2013} & \multicolumn{3}{|c|}{ IDS 2017} \\
\hline & DPA & DNPA & Significance $^{b}$ & DPA & DNPA & Significance \\
\hline \multirow{2}{*}{ Pacífico Central } & 54.4 & 55.3 & & 56.2 & 61.1 & \multirow{2}{*}{ 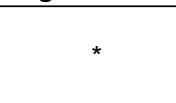 } \\
\hline & & \pm 8.8 & & & \pm 10.3 & \\
\hline \multirow{2}{*}{ Chorotega } & 53.6 & 56.8 & & 55.7 & 59.6 & \\
\hline & \pm 9.2 & \pm 8.5 & & \pm 10.2 & \pm 9.9 & \\
\hline \multirow{2}{*}{ Central } & 58.8 & 67.8 & \multirow{2}{*}{ ** } & 62.4 & 70.9 & \multirow{2}{*}{ ** } \\
\hline & \pm 14.5 & \pm 11.9 & & \pm 14.9 & \pm 12.7 & \\
\hline \multirow{2}{*}{ Country } & 52.9 & 61.4 & \multirow{2}{*}{ ** } & 55.4 & 64.9 & \multirow{2}{*}{ ** } \\
\hline & \pm 13.3 & \pm 13.9 & & \pm 13.9 & \pm 14.8 & \\
\hline
\end{tabular}

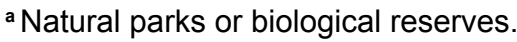

bSignificance of Student's t tests for differences between means. * and ** indicate significance at the $5 \%$ and $1 \%$ levels, respectively.

DPA: Districts with Protected Area. DNPA: Districts without Protected Area.

In the Huetar Norte and Brunca regions, districts with national parks or biological reserves had higher ISD values than those without them. Nevertheless, the difference was statistically significant only in the Huetar Norte region. For the majority of planning regions, districts vary markedly in terms of protected areas and ISD values (Figure 2).

\section{Huetar Norte}

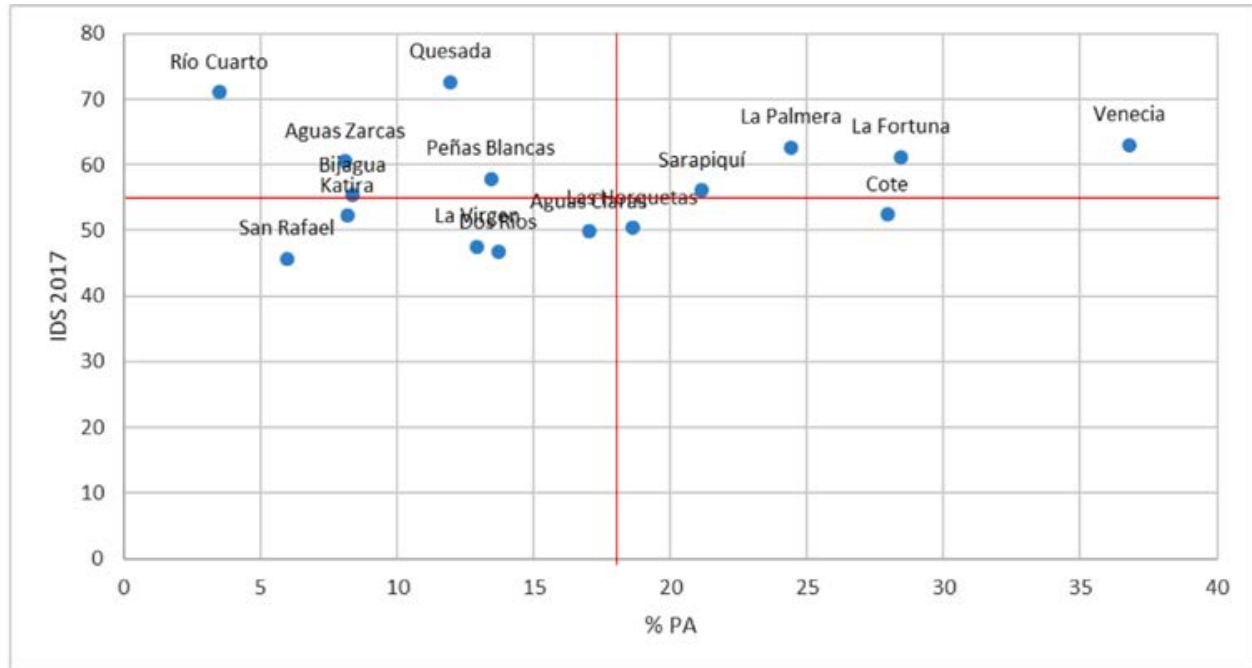




\section{Huetar Caribe}

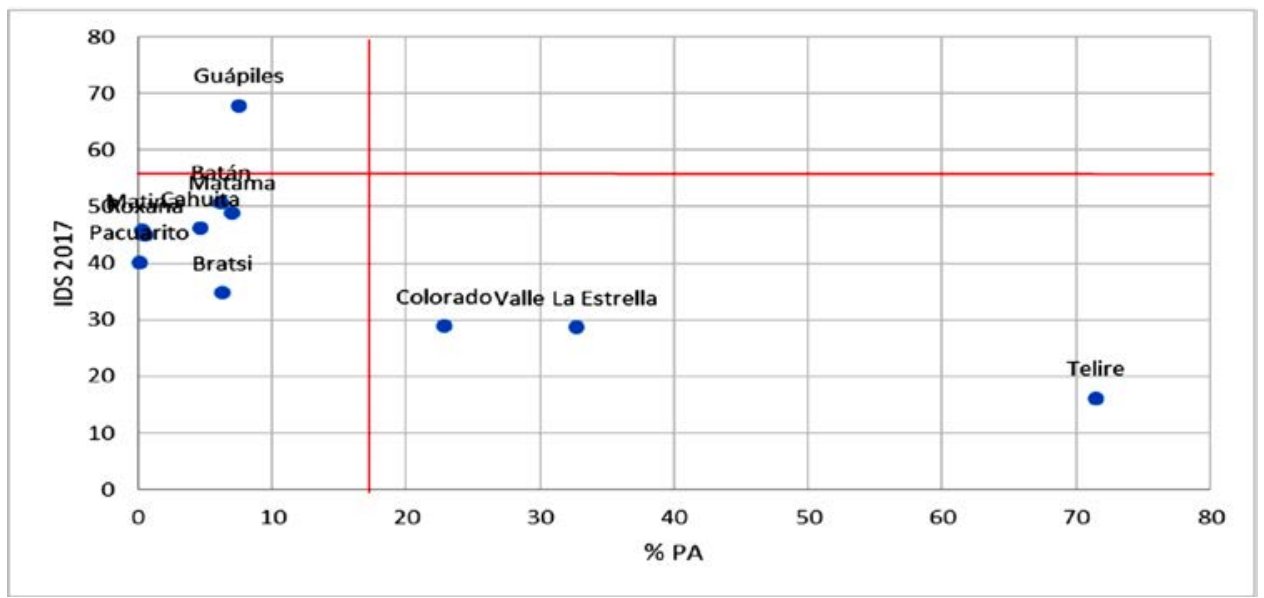

Figure 2. Percentage of protected areas and Social Development Index values for districts of different planning regions of Costa Rica.

\section{Brunca}

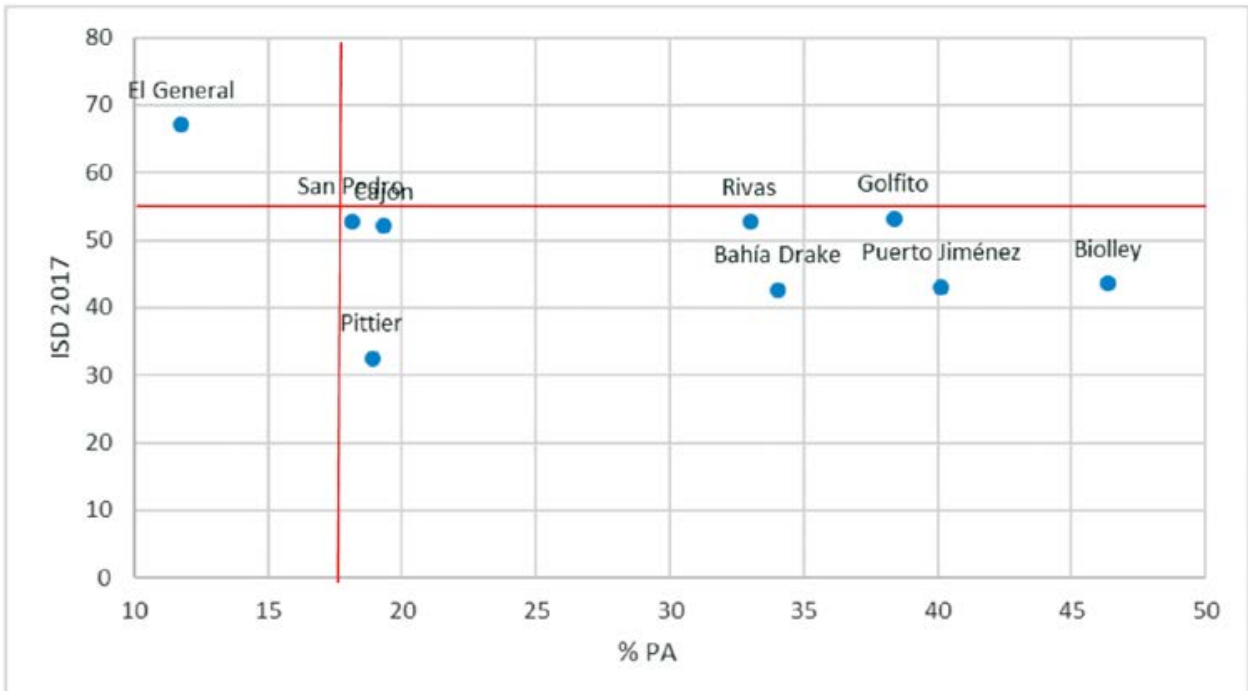

Michael Steven Arroyo-Zeledón y Guillermo Zúñiga-Arias 


\section{Chorotega}

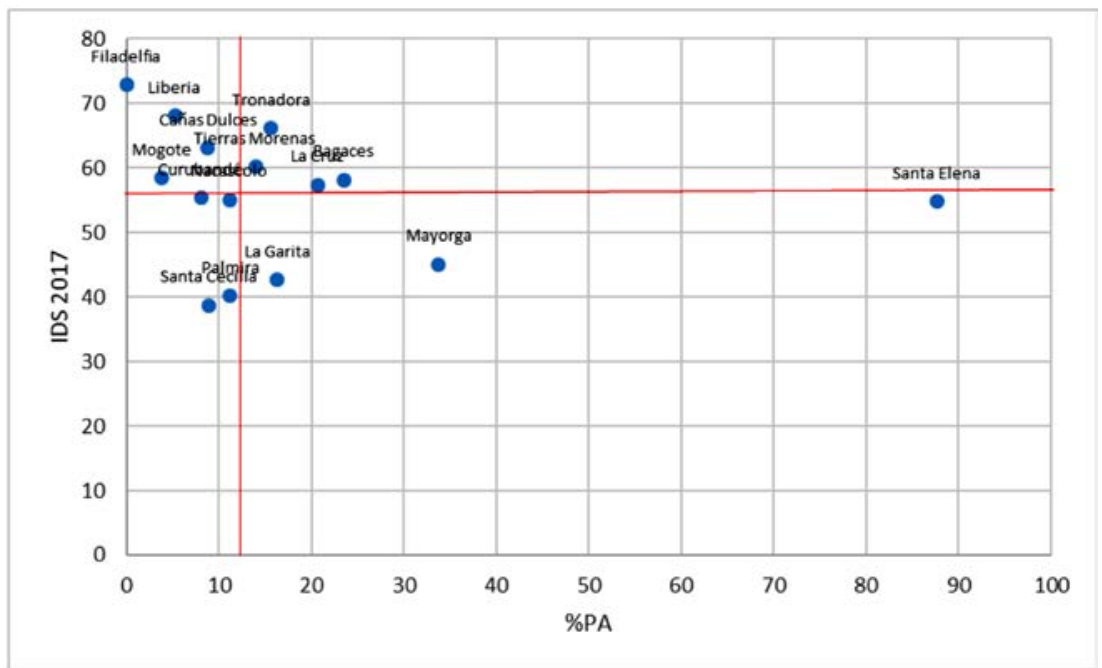

Figure 2. Percentage of protected areas and Social Development Index values for districts in different planning regions of Costa Rica (continued).

\section{Central}

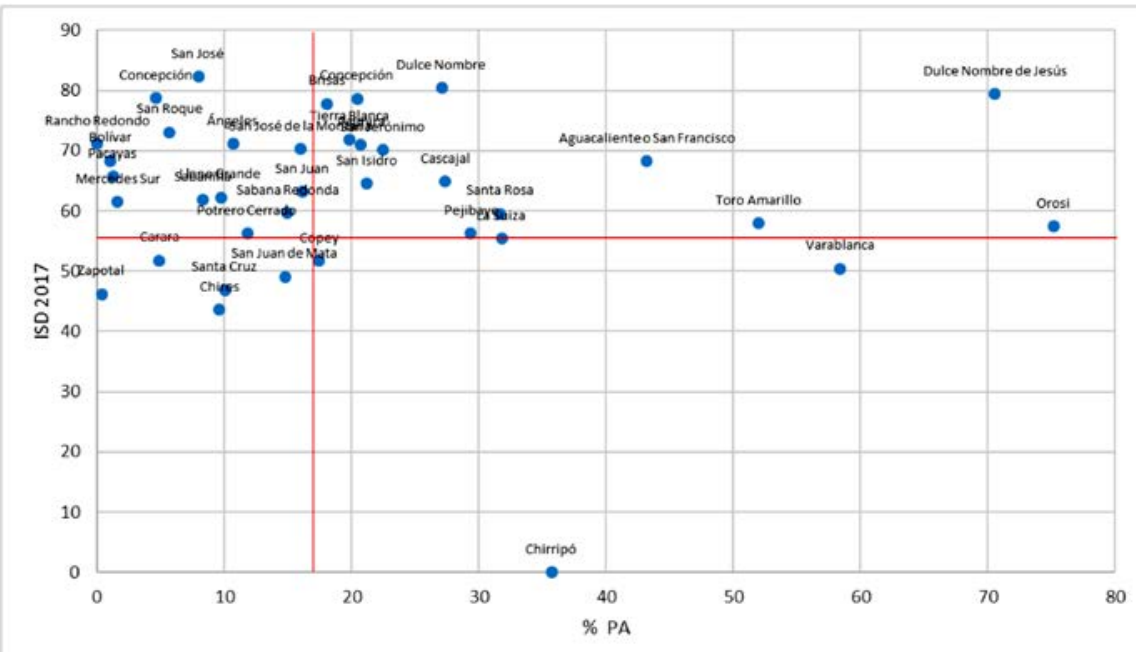

Figure 2. Percentage of protected areas and Social Development Index values for districts in different planning regions of Costa Rica (continued). 
Although there was a negative correlation between the amount of protected areas and IDS in Costa Rican districts, it was weak and not significant. A very similar result was found for the Central region, while stronger negative correlations were found for the Brunca and Chorotega regions, but they were not significant in either case (Table 2).

Table 2

Spearman's correlation coefficient between amount of protected areas (PA) and Index of Social Development (ISD) for districts within the planning regions of Costa Rica

\begin{tabular}{lcc}
\hline \multirow{2}{*}{ Planning Regiona } & \multicolumn{2}{c}{ Correlation PA - ISD (r values) } \\
\cline { 2 - 3 } Huetar Norte & $\mathbf{2 0 1 3}$ & $\mathbf{2 0 1 7}$ \\
\hline Huetar Caribe & 0.25 & 0.35 \\
\hline Brunca & $-0.71^{\star}$ & $-0.94^{\star *}$ \\
\hline Chorotega & -0.12 & 0.07 \\
\hline Central & -0.20 & -0.25 \\
\hline Costa Rica & -0.01 & -0.15 \\
\hline
\end{tabular}

* Indicates significance at the $10 \%$ level. ${ }^{a}$ The Pacífico Central region is not included, since only one district (Tárcoles) had an area protected as a national park.

The Huetar Caribe was the only region that presented a negative and significant relationship between the area of land included in national parks or biological reserves and values of the ISD. The Huetar Norte region presented a positive relationship between the variables, but it was not statistically significant (Table 2 ).

\section{DISCUSSION}

The percentage of districts with at least $5 \%$ of their land under the two most restrictive categories of protection in Costa Rica reflects the country's commitment to conservation of biodiversity, which it is expected to maintain in the future. The effectiveness of these efforts, however, will also strongly depend on the capability of its population to satisfy its basic needs.

Despite the significant difference in poverty levels between Costa Rican districts with and without national parks or biological reserve areas, it cannot be concluded from the results of this investigation that larger areas of protected land in a district are correlated with increased poverty. This 
only was only found to occur in the Huetar Caribe region, making it a priority to revise the strategies for preservation of natural resources in this region since the effectiveness of efforts to preserve biodiversity through national parks may face especially serious difficulties in this area.

The results of this investigation for the entire country are consistent with one of the findings of Andam et al. (2010) for the period 1973-2000, and with the geographical correspondence observed by MIDEPLAN (2013, 2017) between areas under some category of protection and districts with the lowest ISD. In this study, districts with national parks or biological reserves were found to have higher levels of poverty. However, this was only found to be the case in two out of the six Costa Rican planning regions, reaffirming the socioeconomic differences between the country's planning regions, and establishing priorities for further research on the conservation of biodiversity and poverty.

Government authorities in Costa Rica should focus their attention urgently on the Central and Huetar Caribe planning regions, to better understand the relationship between poverty and biodiversity protection in these areas. The findings for these regions suggest that effectiveness to conserve biodiversity could be reduced in national parks and/or biological reserves. Additional questions in both regions are whether the preservation of biological diversity is actually limiting the development of a district, or if districts with protected areas do not have the same opportunities to improve the socio-economic conditions of their population as do districts without such areas.

The results for the Huetar Norte region might reflect limits on the positive effects of the presence of protected areas on the the socio-economic condition of local human populations, taking into account that those areas were not created with that purpose in mind. The generation of better development in this region would require working on factors other than increasing the amount of areas for the protection of biodiversity and the attraction of tourism.

It must be emphasized, however, that the protection of biological diversity can favor socio-economic conditions in the Huetar Norte region. This might be a consequence of tourism activities developed around national parks such as Volcán Arenal and Volcán Tenorio. The Huetar Norte region 
can therefore offer an opportunity to study aspects related to successful management of natural resources, which both protects biodiversity and improves the socio-economic development of the local population.

In the Brunca, Pacífico Central and Chorotega regions, the absence of differences in poverty levels between districts with and without areas for national parks or biological reserves indicates that at the district level in these regions preservation of biodiversity may not affect local population's socio-economic development, which is expectable given that the creation of protected areas was never intended to have an impact on poverty. However, as has been suggested by other authors (Adams, \& Hutton 2007; Ferraro, \& Hanauer, 2014), effective strategies for the management of natural resources can produce socio-economic benefits in areas dedicated to the protection of biodiversity.

\section{CONCLUSIONS}

1. The results of this study show that the relationship between conservation of biodiversity and poverty varies between planning regions in Costa Rica, and that analysis of this relationship should therefore take into account the particularities of each region.

2. Further investigation in the Central and Huetar Caribe planning regions will generate more information on how the protection of biodiversity can affect poverty. This is especially relevant in the Huetar Caribe region, where larger protected areas within districts were related to higher levels of poverty.

3. In the Huetar Norte region, the results of this investigation support the conclusion that national parks could favor improved socio-economic conditions of the local population. Analyzing the way in which such benefits may be obtained could provide effective strategies for the preservation of biodiversity in other planning regions. 


\section{REFERENCES}

Adams, W.M., Aveling, R., Brockington, D., Dickson, B., Elliott, J., Hutton, D., ... Wolmer, W. (2004). Biodiversity conservation and the eradication of poverty. Science, 306, 1146-1149. DOI: 10.1126/science.1097920

Adams, W.M., \& Hutton, J. (2007). People, parks and poverty: political ecology and biodiversity conservation. Conservation and Society 5(2), 147-183. Retrieved from: http://www.conservationandsociety. org/temp/ConservatSoc52147-3960685_110006.pdf

Andam, K.S., Ferraro, P.J., Sims., K.R.E., Healy, A., \& Holland, M.B. (2010). Protected areas reduced poverty in Costa Rica and Thailand. Proceedings of the National Academy of Sciences, 107(22), 999610001. DOI: 10.1073/pnas.0914177107

Alvarado, R. 2003. Regiones y cantones de Costa Rica. Serie Cantones de Costa Rica No. 2. San José, CR. Instituto de Fomento y Asesoría Municipal (IFAM). Retrieved from: http://www.ifam.go.cr/docs/ regiones-cantones.pdf.

Bertsch, F. (2006). El recurso tierra en Costa Rica. Agronomía Costarricense, 30(1), 133-156.Retrieved from https://revistas.ucr.ac.cr/index.php/ agrocost/article/view/6838/6525

Cernea, M.M., \& Schmidt-Soltau, K. (2006). Poverty risks and national parks: policy issues in conservation and resettlement. World Development, 34(10), 1808-1830. DOI: 10.1016/j.worlddev.2006.02.008

De Groot, R., Brander, L., Van der Ploeg, S., Costanza, R., Bernard, F., Braat, L., ... Van Beukering, P. (2012). Global estimates of the value of ecosystems and their services in monetary units. Ecosystem Services, 1, 50-61. DOI: 10.1016/j.ecoser.2012.07.005

De Sherbinin, A. (2008). Is poverty more acute near parks? An assessment of infant mortality rates around protected areas in developing countries. Oryx, 42(1), 26-35. Retrieved from https://doi.org/10.1017/ S0030605308000781 
Donato, F. (2011). Biodiversidad. Biocenosis, 24(1-2), 1-8. Retrieved from: https://investiga.uned.ac.cr/revistas/index.php/biocenosis/article/ view/1197/1233

Ferraro, P.J., \& Hanauer, M.H. (2011). Protecting ecosystems and alleviating poverty with parks and reserves: 'win-win' or tradeoffs? Environmental Resource Economics, 48, 269-286. DOI: 10.1007/ s10640-010-9408-Z

Ferraro, P.J., Hanauer, M.M., \& Sims, K.R.E. (2011). Conditions associated with protected area success in conservation and poverty reduction. Proceedings of the National Academy of Sciences, 108(34), 1391313918. DOI: 10.1073/pnas.1011529108

Ferraro, P.J., \& Hanauer, M.M. (2014). Quantifying causal mechanisms to determine how protected areas affect poverty through changes in ecosystem services and infrastructure. Proceedings of the National Academy of Sciences, 111(11), 4332-4337. DOI: 10.1073/ pnas. 1307712111

Figueroa, F., Sánchez-Cordero, V., Illoldi-Rangel, P., \& Linaje, M. (2011). Evaluación de la efectividad de las áreas protegidas para contener procesos de cambio en el uso del suelo y la vegetación. ¿Un índice es suficiente? Revista Mexicana de Biodiversidad, 82, 951-963. Retrieved from: http://www.scielo.org.mx/pdf/rmbiodiv/v82n3/v82n3a20.pdf

Fisher, B., \& Christopher, T. (2007). Poverty and biodiversity: measuring the overlap of human poverty and the biodiversity hotspots. Ecological Economics, 62, 93-101. DOI: 10.1016/j.ecolecon.2006.05.020

IGN (Instituto Geográfico Nacional, CR) 2014. Sistema nacional de información territorial. Servicios WFS. San José, CR. Retrieved from: http://www.snitcr.go.cr/index.php?option=com_content\&view=article

INEC (Instituto Nacional de Estadística y Censos, CR). (2010). Actualización metodológica para la medición del empleo y la pobreza. San José, CR. Retrieved from: http://www.inec.go.cr/enaho/result/resultados.aspx

INEC (Instituto Nacional de Estadística y Censos, CR). (2014a). Encuesta nacional de hogares (ENAHO). Principales características de los 
hogares y de las personas por nivel de pobreza, según región. San José, CR. Retrieved from: http://www.inec.go.cr/enaho/result/ pobreza.aspx

INEC (Instituto Nacional de Estadística y Censos, CR). (2014b). Encuesta nacional de hogares (ENAHO). Promedio de valor de línea de pobreza por zona (online). San José, CR. Retrieved from http://www. inec.go.cr/bincri/RpWebEngine.exe/Portal?BASE=ENAHO2014

MIDEPLAN (Ministerio de Planificación Nacional y Política Económica, CR) (2013). Costa Rica: índice de desarrollo social 2013. San José, CR. Retrieved from: http://documentos.mideplan.go.cr/alfresco/d/d/ workspace/SpacesStore/8919cc42-afa2-4283-ab37-837547406763/ IDS\%202013.pdf.

MIDEPLAN (Ministerio de Planificación Nacional y Política Económica, CR) (2018). Costa Rica: índice de desarrollo social 2017. San José, CR. Retrieved from: https://documentos.mideplan.go.cr/ share/s/6I2bxJTjQqWPGoLkFtG9Xw

Phillips, A. (2004). The history of the international system of protected area management categories. Parks, 14(3), 4-14. Retrieved from: https:// www.researchgate.net/publication/284585491_The_History_of_the International_System_of_Protected_Area_Management_Categories

Powell, G.V.N., Barborak, J., \& Rodriguez, M. (2000). Assessing representativeness of protected natural areas in Costa Rica for conserving biodiversity: a preliminary gap analysis. Biological Conservation, 93, 35-41. DOI: 10.1016/S0006-3207(99)00115-9

Sanderson, S. (2005). Poverty and conservation: the new century's "peasant question?". World Development, 33(2), 323-332. DOI: 10.1016/j.worlddev.2004.07.016

SINAC (Sistema Nacional de Áreas de Conservación, CR). (2007). GRUAS II: propuesta de ordenamiento territorial para la conservación de la biodiversidad de Costa Rica First edition. Volume 1. San José, Costa Rica:autor. 
SINAC (Sistema Nacional de Áreas de Conservación, CR). (2010). Políticas para las áreas silvestres protegidas (ASP) del sistema nacional de áreas de conservación (SINAC). San José, CR: autor.

Turner, W.R., Brandon, K., Brooks, T.M., Gascon, C., Gibbs, H.K., Lawrence, K.S., ... Selig, E.R. (2012). Global biodiversity conservation and the alleviation of poverty. BioScience, 62(1), 85-92. Retrieved from: https://www.conservation.org/publications/Documents/Turner-etal_2012_Conservation-and-poverty-alleviation.pdf

Upton, C., Ladle, R., Hulme, D., Jiang, T., Brockington, D., \& Adams, W.M. (2008). Are poverty and protected area establishment linked at a national scale? Oryx, 42(1), 19-25. DOI: 10.1017/ S0030605307001044

Waldron, A., Mooers, A.O., Miller, D.C., Nibbelink, N., Redding, D., Kuhn, T.S., ... \& Gitteleman, J.L. (2013). Targeting global conservation funding to limit immediate biodiversity declines. PNAS, 110(29), 12144-12148. DOI: 10.1073/pnas.1221370110

Watson, J.E.M., Dudley, N., Segan, D.B., \& Hockings, M. (2014). The performance and potential of protected areas. Nature, 515, 67-73. DOI: 10.1038/nature13947 